\title{
Italy: Political Developments and Data in 2018
}

\author{
CATERINA FROIO \\ Centre for European Studies and Comparative Politics, Sciences Po
}

PIETRO CASTELLI GATTINARA

Centre for Research on Extremism, University of Oslo

\section{Introduction}

The year 2018 shattered Italian politics. During the campaign for national elections in February 2018, the police arrested right-wing extremist Luca Traini after injuring six migrants in the city of Macerata in central Italy. A few weeks later, in March, the general elections marked the success of Luigi Di Maio’s M5s (Five Star Movement) and Matteo Salvini’s LN (League) and relegated the parties that dominated the previous phase - PD (Democratic Party) and FI (Go Italy) - and their leaders - Matteo Renzi and Silvio Berlusconi- to the margins of Italy's party system. Since no political coalition or party won an outright majority at the elections, the elections resulted in a hung parliament. After three months of negotiations, the LN and M5S eventually managed to strike the deal that set up the first Conte government. While the issue of migration shaped public debates and policymaking, putting Italy's bilateral relations with France under strain, the Italian government's difficulty to pass the 2019 budget plan triggered tensions with the EU commissions and instability on the financial markets. 


\section{Election report}

The general election was the most important political event of the year. The election was called in March and during the electoral campaign right-wing extremist Luca Traini injured six migrants in the city of Macerata. The turnout was 72.9 per cent, the lowest in history. This was the result of a general mood of discontent and distrust towards politics. The rate of approval and confidence in political parties attained a record low: only 8 per cent of people expressed any trust, and more than 40 per cent considered political parties useless, such that Italian democracy could work without them (source: DEMOS and PI). In this context, Luigi di Maio's Five Stars Movement (M5S) and Matteo Salvini's Lega were both the expression and recipients of this wave of discontent. Di Maio and Salvini led storming electoral campaigns all over Italy, receiving a level of attention in the media that had not been seen for many years by any other political leader, Silvio Berlusconi included. At the end of the electoral campaign, the M5S became the first party with around 30 per cent in the Lower Chamber (compared to 25 per cent in 2013). The League came second obtaining the best score in the history of the party, around 17 per cent (compared to 4 per cent in 2013). Both parties overtook the PD, which received 18 per cent (compared to 25 per cent in 2013) and Forza Italia that received 14 per cent (compared to 21 per cent in 2013). The centrist coalition created by Mario Monti disappeared. The votes of Italian residents abroad did not change these figures.

The M5S and the Lega results represented an extraordinary performance in comparative terms. They highlighted the fiasco of the PD and of the centre-right coalition led by Silvio Berlusconi. The PD obtained the worst result since its birth in 2007 and did not increase its share of the vote compared to the previous regional and European elections. The low-profile campaign and the wounds left by the constitutional referendum in December 2016 championed by Matteo Renzi 
led to a split in the PD and the emergence of the party "Free and Equal" (LEU, Liberi e Uguali). This new party was founded in December 2017, just before the elections, by former President of the Senate Pietro Grasso (see Castelli Gattinara and Froio 2018). LEU's final score was much lower than forecast. It did not even obtain 5 per cent of the vote. In this anti-politics climate, members of the former centre-left government thus lost electoral support . In contrast, Berlusconi's centre-right coalition made quite a comeback, even if Berlusconi's party (Forza Italia) lost more than 7 per centage points. Salvini's direct and very intense involvement in the electoral campaign led the centre-right coalition to poll ahead of the centre-left one. Compared to 2013, the two competing coalitions - led by Berlusconi on the right and Renzi on the left performed very differently. The left lost 7 per cent of the votes while the right increased its score by around 6 per cent of the votes.

The electoral campaign focused on immigration and the Dublin Regulation on the arrival of migrants, Italy's budget, Lega's proposal of flat tax and M5S' proposal of basic income. In addition, 'anti-politics', which was expressed vocally by di Maio's M5S and Salvini's Lega, was a leitmotiv of the campaign. The elections resulted in a hung parliament with no clear majority. Negotiations lasted for three months, until 1 June when a government coalition was formed between the M5S and the League.

Table 1.1 Elections to the lower house of parliament (Camera dei Deputati) in Italy in 2018

\begin{tabular}{ll}
\hline Date of election & 04 March 2018 \\
Total seats & Italy \\
Electorate & 618 \\
& $46,505,350$ \\
Total votes cast & \\
Turnout & $33,923,321$ \\
Valid votes cast & $72.9 \%$ \\
\hline
\end{tabular}

Abroad

12

$4,230,854$

$1,262,422$

$29,8 \%$

$1,123,429$
Overall $630^{\mathrm{a}}$ $50,736,20$ $35,185,74$ $69.3 \%$ $33,964,45$ 


\begin{tabular}{|c|c|c|c|c|c|c|c|c|c|}
\hline \multirow[b]{3}{*}{ Party } & \multirow{2}{*}{\multicolumn{3}{|c|}{ Italy }} & \multicolumn{5}{|c|}{ Abroad } & \multirow[b]{2}{*}{ Votes } \\
\hline & & & & & & Votes & Seats & & \\
\hline & $\mathrm{N}$ & $\%$ & $\Delta \%$ & $\mathrm{~N}$ & $\%$ & $\mathrm{~N}$ & $\mathrm{~N}$ & $\mathrm{~N}$ & $\%$ \\
\hline Five Stars Movement/Movimento 5 Stelle (M5S) & $10,743,066$ & $32,6 \%$ & $+7.0 \%$ & 225 & $35.9 \%$ & 188,933 & 1 & $10,931,999$ & $32.2 \%$ \\
\hline League/Lega $(\mathrm{L})$ & $5,698,687$ & $17.3 \%$ & $+13.2 \%$ & 123 & $19.6 \%$ & - & - & $5,698,687$ & $17.3 \%$ \\
\hline Go Italy/Forza Italia $(\mathrm{FI})^{\mathrm{b}}$ & $4,596,956$ & $14.0 \%$ & $-7.6 \%$ & 103 & $16,3 \%$ & - & - & $4,596,956$ & $14.0 \%$ \\
\hline Brothers of Italy/Fratelli d'Italia (FdI) & $1,429,550$ & $4.3 \%$ & $+2.4 \%$ & 32 & $5.0 \%$ & - & - & $1,429,550$ & $4.3 \%$ \\
\hline Us with Italy/Noi con l'Italia-UDC (NI-UDC) & 472,152 & $1.3 \%$ & $-0.5 \%$ & 4 & $0.6 \%$ & - & - & 472,152 & $1.3 \%$ \\
\hline $\begin{array}{l}\text { Salvini-Berlusconi-Meloni/Salvini-Berlusconi-Meloni } \\
(\text { SBM })^{\mathrm{c}}\end{array}$ & - & - & - & - & - & 232,078 & 3 & 232,078 & $0.7 \%$ \\
\hline Total Centre Right Coalition & $12,152,158$ & $37.0 \%$ & $+7.8 \%$ & 262 & $41.5 \%$ & 232,078 & 3 & $12,384,236$ & $36.5 \%$ \\
\hline Democratic Party/Partito Democratico (PD) & $6,161,896$ & $18.8 \%$ & $-6.6 \%$ & 107 & $17.0 \%$ & 285,429 & 5 & $6,447,325$ & $18.4 \%$ \\
\hline +Europe/+Europa $(+\mathrm{E})$ & 841,468 & $2.6 \%$ & - & 2 & $0.3 \%$ & 60,859 & 1 & 902,327 & $2.6 \%$ \\
\hline Italy Europe Together/Italy Europe Together & 190,601 & $0.6 \%$ & - & 1 & $0.1 \%$ & - & - & 190,601 & $0.6 \%$ \\
\hline People's List Lorenzin/Civica Popolare Lorenzin (CL) & 178,107 & $0.5 \%$ & - & 2 & $0.3 \%$ & - & - & 178,107 & $0.5 \%$ \\
\hline South Tyrol People Party/Sudtiroler Volkspartei (SVP) & 134,651 & $0.4 \%$ & $0.0 \%$ & 4 & $0.6 \%$ & - & - & 134,651 & $0.4 \%$ \\
\hline Total Centre Left Coalition & $7,506,723$ & $22.9 \%$ & $6.6 \%$ & 116 & $18.4 \%$ & 746,288 & 6 & $8,253,011$ & $23.5 \%$ \\
\hline Free and Equals/Liberi e Uguali $(\mathrm{LeU})^{\mathrm{d}}$ & $1,114,799$ & $3.4 \%$ & $+0.2 \%$ & 14 & $2.2 \%$ & 61,714 & 0 & $1,176,513$ & $3.3 \%$ \\
\hline Others & $1,335,772$ & $4.1 \%$ & $-0.4 \%$ & 0 & $0.0 \%$ & 169,901 & 2 & $1,505,674$ & $4.3 \%$ \\
\hline
\end{tabular}

Notes: a Totals add up to 629 because the seat of Valle d'Aosta is allocated in a single-member district (SMD) system), and in 2018 it was won by M5S.

${ }^{\mathrm{b}}$ Changes are calculated with respect to the former party People of Freedom/Il Popolo della Libertà.

${ }^{\mathrm{c}}$ This is the joint electoral list presented by Go Italy, Brothers of Italy and League for the vote of Italians living abroad.

${ }^{\mathrm{d}}$ Changes are calculated with respect to the party Left, Ecology, Freedom/Sinistra, Ecologia, Libertà

Source: Ministry of the Interior (2019). 
Table 1.2 Elections to the upper house of parliament (Senato della Repubblica) in Italy in 2018

\begin{tabular}{|c|c|c|c|c|c|c|c|c|c|}
\hline \multirow{2}{*}{ Date of election } & \multicolumn{9}{|c|}{ 04 March 2018} \\
\hline & \multicolumn{5}{|c|}{ Italy } & \multicolumn{3}{|l|}{ Abroad } & Overall \\
\hline Total seats & \multicolumn{5}{|l|}{307} & \multicolumn{3}{|l|}{6} & $314^{\mathrm{a}}$ \\
\hline Electorate & \multicolumn{5}{|l|}{$42,780,033$} & \multicolumn{3}{|l|}{$3,835,780$} & $46,615,8$ \\
\hline Total votes cast & \multicolumn{5}{|l|}{$31,231,814$} & \multicolumn{3}{|l|}{$1,160,985$} & $32,392,79$ \\
\hline Turnout & \multicolumn{5}{|l|}{$73.0 \%$} & \multicolumn{3}{|l|}{$30.3 \%$} & $69.0 \%$ \\
\hline Valid votes cast & \multicolumn{5}{|l|}{$30,210,363$} & \multicolumn{3}{|l|}{$1,032,063$} & $31,242,42$ \\
\hline \multirow[t]{3}{*}{ Share of valid votes } & \multicolumn{5}{|l|}{$96.7 \%$} & \multicolumn{3}{|l|}{$88,9 \%$} & $96.0 \%$ \\
\hline & \multicolumn{5}{|c|}{ Italy } & \multicolumn{3}{|c|}{ Abroad } & \\
\hline & \multicolumn{3}{|c|}{ Votes } & \multicolumn{2}{|c|}{ Seats } & \multirow{2}{*}{$\begin{array}{c}\text { Votes } \\
\mathrm{N}\end{array}$} & \multirow{2}{*}{$\begin{array}{c}\text { Seats } \\
\mathrm{N}\end{array}$} & \multicolumn{2}{|r|}{ Votes } \\
\hline Party & $\mathrm{N}$ & $\%$ & $\Delta \%$ & $\mathrm{~N}$ & $\%$ & & & $\mathrm{~N}$ & $\%$ \\
\hline Five Stars Movement/Movimento 5 Stelle (M5S) & $9,733,928$ & $32.2 \%$ & $+8.4 \%$ & 111 & $34.7 \%$ & 182,715 & 0 & $9,916,643$ & $31.7 \%$ \\
\hline League/Lega $(\mathrm{L})$ & $5,321,537$ & $17.6 \%$ & $+13.3 \%$ & 58 & $18.1 \%$ & - & - & $5,321,537$ & $18.1 \%$ \\
\hline Go Italy/Forza Italia $(\mathrm{FI})^{\mathrm{b}}$ & $4,358,004$ & $14.4 \%$ & $-7.9 \%$ & 55 & $17.2 \%$ & - & - & $4,358,004$ & $14.4 \%$ \\
\hline Brothers of Italy/Fratelli d'Italia $(\mathrm{FdI})$ & $1,286,606$ & $4.3 \%$ & $+2.4 \%$ & 18 & $5.6 \%$ & - & - & $1,286,606$ & $4.3 \%$ \\
\hline Us with Italy/Noi con l'Italia-UDC (NI-UDC) & 361,402 & $1.2 \%$ & - & 4 & $1.3 \%$ & 10,856 & 0 & 372,258 & $1.2 \%$ \\
\hline $\begin{array}{l}\text { League-Go Italy-Brothers of Italy with Meloni/Lega- } \\
\text { Forza Italia-Fratelli d'Italia con Meloni (LFIFdI) }^{\mathrm{b}}\end{array}$ & - & - & - & - & - & 226,885 & 2 & 226,885 & $0.7 \%$ \\
\hline Total Centre Right Coalition & $11,327,549$ & $37.5 \%$ & $+6.8 \%$ & 135 & $42.2 \%$ & 237,741 & 2 & $11,565,290$ & $37.0 \%$ \\
\hline Democratic Party/Partito Democratico (PD) & $5,783,360$ & $19.1 \%$ & $-8.3 \%$ & 51 & $15.9 \%$ & 279,489 & 2 & $6,062,849$ & $19.4 \%$ \\
\hline +Europe/+Europa $(+\mathrm{E})$ & 714,821 & $2.4 \%$ & - & 1 & $0.3 \%$ & 55,625 & 0 & 770,446 & $2.5 \%$ \\
\hline Italy Europe Together/Italy Europe Together & 163,454 & $0.5 \%$ & - & 1 & $0.3 \%$ & - & - & - & - \\
\hline People's List Lorenzin/Civica Popolare Lorenzin (CL) & 157,282 & $0.5 \%$ & - & 1 & $0.3 \%$ & 32.660 & 0 & 157,315 & $0.5 \%$ \\
\hline South Tyrol People Party/Sudtiroler Volkspartei (SVP) & 128,282 & $0.4 \%$ & - & 3 & $0.9 \%$ & - & - & - & - \\
\hline Total Centre Left Coalition & $6,947,199$ & $23.0 \%$ & $-8.6 \%$ & 57 & $17.8 \%$ & 367,774 & 2 & $7,314,973$ & $23.4 \%$ \\
\hline Free and Equals/Liberi e Uguali $(\mathrm{LeU})^{\mathrm{c}}$ & 991,159 & $3.3 \%$ & $+0.4 \%$ & 4 & $1.3 \%$ & 57,761 & 0 & $1,048,920$ & $3.4 \%$ \\
\hline Others ${ }^{\mathrm{d}}$ & $1,210,709$ & $0.4 \%$ & $-5.4 \%$ & 0 & $0.0 \%$ & 186,072 & 2 & $1,396,781$ & $4.5 \%$ \\
\hline
\end{tabular}

Notes: ${ }^{\text {a }}$ Totals add up to 313 because the seat of Valle d'Aosta is allocated in a single-member district (SMD) system, and in 2018 it was won by the centre-left coalition between PD and the Vallée d'Aoste ethno-regionalist party.

${ }^{\mathrm{b}}$ This is the joint electoral list presented by Go Italy, Brothers of Italy and League for the vote of Italians living abroad. Changes are calculated with respect to the former party People of Freedom/Il Popolo della Libertà.

${ }^{\mathrm{c}}$ Changes are calculated with respect to the party Left, Ecology, Freedom/Sinistra, Ecologia, Libertà

${ }^{\mathrm{d}}$ The two seats were won by political parties representing Italians abroad: the Associative Movement Italians Abroad/Movimento Associativo Italiani all'Estero (MAIE) and South American Union Italian Emigrants/Unione Sudamericana degli Italiani (USEI).

Source: Ministry of the Interior (2019). 


\section{Cabinet report}

The results of the elections provoked a three month political gridlock over government formation, since all parties and coalitions in parliament fell short of an absolute majority. The conundrum revolved around a complex web of mutual vetoes. Di Maio put a veto on a tie-up with Forza Italia, which made it impossible to sign an alliance between the Five Star Movement - the largest single party - and the centre-right alliance - the largest coalition. In return, Berlusconi opposed the talks between its allies and M5S, and Salvini reiterated his unavailability to support grand-coalition governments involving the centre-left. Meanwhile, the second largest in Parliament, PD was stalled by major internal divisions: while the temporary party head Martina tried some tentative approaches towards M5S, former leader Renzi used his influence in the party to oppose any such deal.

In this context, the President of the Republic Sergio Mattarella supervised two consecutive rounds of government consultations and three unsuccessful exploratory mandates by the speakers of the chambers. The impasse broke only once Mr. Mattarella envisaged the nomination of an interim technocratic government, which would rule until new elections. In response, Berlusconi gave up his veto on the negotiations between Salvini and Di Maio. In late May, the League and M5S could finally agree on a "contract for a government of change" and put forward law professor Giuseppe Conte to oversee the formation of a Cabinet. At first, President Mattarella turned down the proposed Cabinet based on concerns over the figure of Eurosceptic economist Paolo Savona as minister of finance. After an unsuccessful mandate to former IMF official Carlo Cottarelli, who tried to find parliamentary support for a technocratic executive, M5S and Lega accepted the need to opt for a more accommodating figure on economic policy (economics professor Giovanni Tria). In a very tense context, on 1 June Prof. Giuseppe Conte was nominated prime minister, with 
Salvini and Di Maio as Deputy prime ministers and Savona on European affairs. In this cabinet,

Salvini and Di Maio hold the role of Interior Minister and of Minister of Economic Development,

Labour and Social Policies respectively.

Table 2.1 Cabinet composition of Gentiloni I in Italy in 2018.

\begin{tabular}{|c|c|c|c|c|c|c|}
\hline $\begin{array}{l}\text { Duration of cabinet } \\
\text { Period covered by table }\end{array}$ & $\begin{array}{l}\text { Inception } \\
\text { From }\end{array}$ & $\begin{array}{l}\text { 12 December } 2016 \\
1 \text { January } 2018\end{array}$ & $\begin{array}{l}\text { Dissolution } \\
\text { Until }\end{array}$ & \multicolumn{3}{|c|}{ 01 June 2018} \\
\hline Type of cabinet & \multicolumn{2}{|c|}{ Oversized coalition $(\mathrm{OC})^{\mathrm{a}}$} & \multirow{2}{*}{\multicolumn{2}{|c|}{ Seats held by women }} & & \\
\hline \multirow{2}{*}{\multicolumn{2}{|c|}{ Party/gender composition on 1 January 2018}} & Seats in cabinet & & & \multicolumn{2}{|c|}{ Seats in parliament } \\
\hline & & $\mathrm{N} \quad \%$ & \multirow{2}{*}{$\mathrm{N}$} & $\%$ of party & \multicolumn{2}{|c|}{$\mathrm{N} \%$} \\
\hline Democratic Party/Partito & Democratic (PD) & $73.7 \%$ & & $28.6 \%$ & 281 & $44.7 \%$ \\
\hline Popular Alternative /Altel & nativa Popolare & $10.5 \%$ & 1 & $33.3 \%$ & 22 & $3.5 \%$ \\
\hline Independents & & $10.5 \%$ & 0 & $0.0 \%$ & - & - \\
\hline Totals & & $100 \%$ & 5 & $26.3 \%$ & 303 & $48.2 \%$ \\
\hline \multicolumn{7}{|c|}{ B. $\quad$ Composition of Gentiloni I cabinet on 1 January 2018} \\
\hline \multicolumn{7}{|c|}{ See previous editions of the Political Data Yearbook for Italy or http://politicaldatayearbook.com } \\
\hline \multicolumn{7}{|c|}{ C. $\quad$ Changes in composition of Gentiloni I cabinet during 2018} \\
\hline Ministerial title & Outgoing minister & \multirow{2}{*}{$\begin{array}{l}\text { Outgoing date } \\
13 \text { March } 2018\end{array}$} & Incoming min & & \multicolumn{2}{|c|}{ Comments } \\
\hline $\begin{array}{l}\text { Ministry of Agricultural, } \\
\text { Food and Forestry } \\
\text { Policies }\end{array}$ & $\begin{array}{l}\text { Maurizio Martina (1978, } \\
\text { male, PD) }\end{array}$ & & \multicolumn{2}{|c|}{$\begin{array}{l}\text { Paolo Gentiloni Silveri } \\
\text { (1954, male, PD) }\end{array}$} & \multicolumn{2}{|c|}{$\begin{array}{c}\text { Nominated secretary of } \\
\text { Democratic Party }\end{array}$} \\
\hline \multirow[t]{2}{*}{ Party/gender composition } & on 1 June 2018 & Seats in cabinet & \multicolumn{2}{|c|}{ Seats held by women } & \multicolumn{2}{|c|}{ Seats in parliament } \\
\hline & & $\mathrm{N} \quad \%$ & $\mathrm{~N}$ & $\%$ of party & $\mathrm{N}$ & $\%$ \\
\hline
\end{tabular}

Notes: a Includes only cabinet-level ministers. Since the government also includes a number of junior ministers from several other parties, the actual type of government is an Oversized Coalition (OC) throughout the year.

Source: Governo Italiano (2019).

Table 2.2 Cabinet composition of Conte I in Italy in 2018.

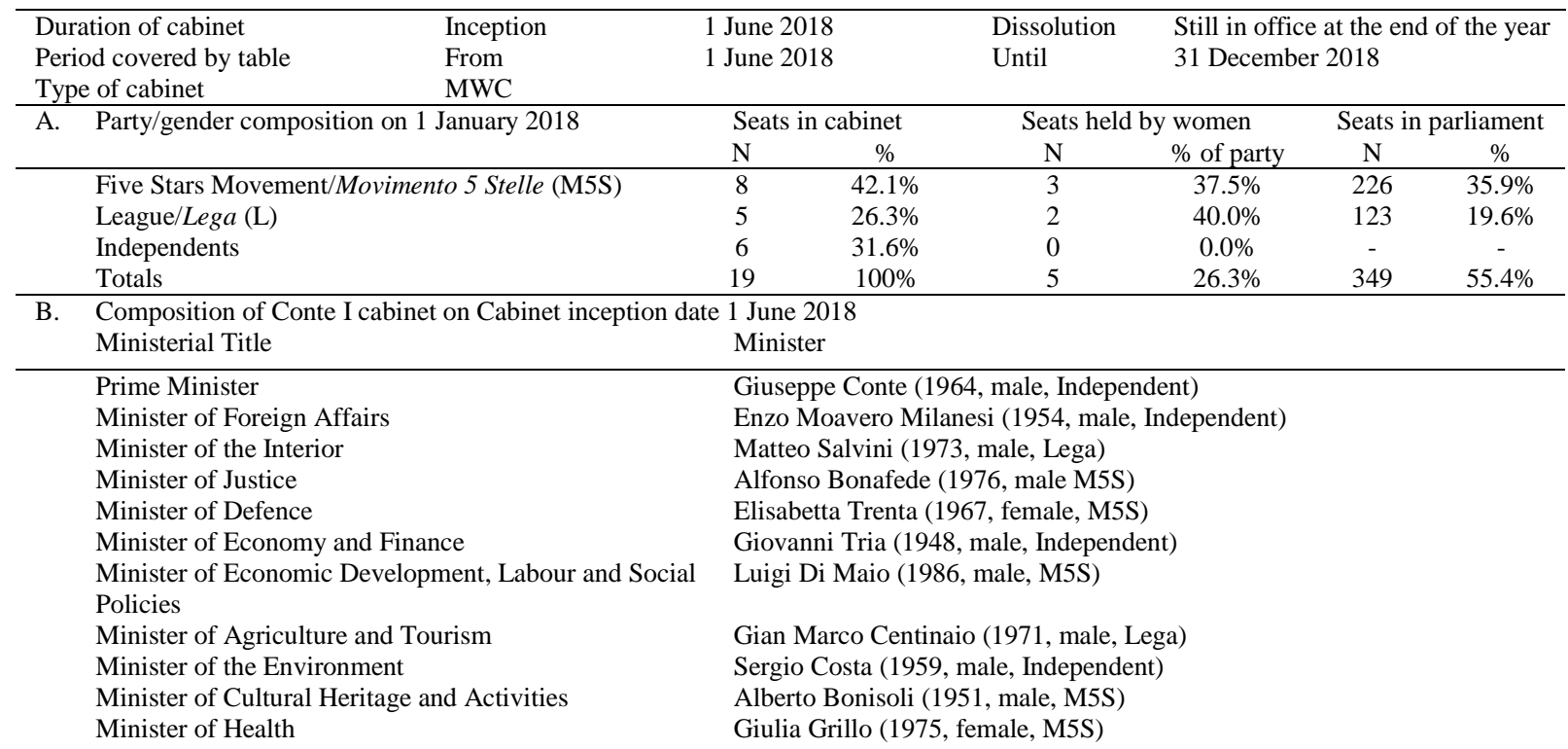


Minister for Parliamentary Relations and Direct

Democracy

Minister of Public Administration

Minister of Regional Affairs

Minister for Southern Italy

Minister for Family and Disability

Minister of European Affairs
Riccardo Fraccaro (1981, male, M5S)

Giulia Bongiorno (1961, female, Lega)

Erika Stefani (1971, female, Lega)

Barbara Lezzi (1972, female, M5S)

Lorenzo Fontana (1980, male, Lega)

Paolo Savona (1936, male, Independent)

\begin{tabular}{|c|c|c|c|c|}
\hline \multirow{2}{*}{ C. } & \multicolumn{4}{|l|}{ Changes in composition of Conte I cabinet during 2018} \\
\hline & Ministerial title $\quad$ Outgoing minister & Outgoing date & \multicolumn{2}{|l|}{ Incoming minister } \\
\hline & None & & & \\
\hline \multirow[t]{2}{*}{ D. } & Party/gender composition on 31 December 2018 & Seats in cabinet & Seats held by women & Seats in parliament \\
\hline & & & $\mathrm{N} \quad \%$ of party & $\mathrm{N} \quad \%$ \\
\hline
\end{tabular}

Source: Governo Italiano (2019).

\section{Parliament report}

The year 2018 radically transformed the Italian political landscape. While some of the parties

that had dominated the parliamentary arena after the 2013 general elections suffered severe

defeats (PD, FI), others entered the lower and upper houses with unprecedented numbers (M5S,

L). This renewal also led to an increase of more than 5 percent points for women among the MPs

in the two houses.

Table 4.1 Party and gender composition of the lower house of parliament (Camera dei Deputati) in Italy in 2018

\begin{tabular}{|c|c|c|c|c|c|c|c|c|c|c|c|c|}
\hline \multirow[b]{4}{*}{ Party } & \multicolumn{4}{|c|}{1 January 2018} & \multicolumn{4}{|c|}{23 March 2018, election } & \multicolumn{4}{|c|}{31 December 2018} \\
\hline & \multicolumn{2}{|c|}{ All } & \multicolumn{2}{|c|}{ Women } & \multicolumn{2}{|c|}{ All } & \multicolumn{2}{|c|}{ Women } & \multicolumn{2}{|c|}{ All } & \multicolumn{2}{|c|}{ Women } \\
\hline & $\mathrm{N}$ & $\%$ & $\mathrm{~N}$ & $\%$ & $\mathrm{~N}$ & $\%$ & $\mathrm{~N}$ & $\%$ & $\mathrm{~N}$ & $\%$ & $\mathrm{~N}$ & $\%$ \\
\hline & & & & & & & & & & & & \\
\hline Democratic Party (PD) & 281 & $44.7 \%$ & 104 & $37.0 \%$ & 111 & $17.6 \%$ & 36 & $32.4 \%$ & 111 & $17.6 \%$ & 36 & $32.4 \%$ \\
\hline Five Stars Movement (M5S) & 88 & $14.0 \%$ & 30 & $34.1 \%$ & 222 & $35.2 \%$ & 95 & $42.8 \%$ & 220 & $34.9 \%$ & 95 & $43.2 \%$ \\
\hline Go Italy (FI) & 56 & $8.9 \%$ & 19 & $33.9 \%$ & 104 & $16.5 \%$ & 38 & $36.5 \%$ & 105 & $16.7 \%$ & 38 & $36.2 \%$ \\
\hline $\begin{array}{l}\text { Article 1, Democratic } \\
\text { Progressive Movement } \\
\text { /Articolo } 1 \text { - Movimento } \\
\text { Democratico e Progressista } \\
\text { (MDP) }\end{array}$ & 43 & $6.8 \%$ & 12 & $27.9 \%$ & - & - & - & - & - & - & - & - \\
\hline $\begin{array}{l}\text { Italian Left-Left, Ecology, } \\
\text { Freedom/Sinistra Italiana- } \\
\text { Sinistra Ecologia Libertà } \\
\text { (SI-SEL). }\end{array}$ & 17 & $2.7 \%$ & 5 & 29.4 & - & - & - & - & - & - & - & - \\
\hline Free and Equals $(\mathrm{LeU})^{\mathrm{a}}$ & - & - & - & - & 14 & $2.2 \%$ & 4 & $28.6 \%$ & 14 & $2.2 \%$ & 4 & $28.6 \%$ \\
\hline Popular Alternative (AP) & 22 & $3.5 \%$ & 3 & $13.6 \%$ & - & - & - & - & - & - & - & - \\
\hline $\begin{array}{l}\text { Civic Choice for Italy/Scelta } \\
\text { Civica per l'Italia (MAIE) }\end{array}$ & 16 & $2.5 \%$ & 1 & $6.2 \%$ & - & - & - & - & - & - & - & - \\
\hline League $(\mathrm{L})^{\mathrm{b}}$ & 22 & $3.5 \%$ & 2 & $9.1 \%$ & 125 & $19.8 \%$ & 34 & $27.2 \%$ & 125 & $19.8 \%$ & 34 & $27.2 \%$ \\
\hline
\end{tabular}




\begin{tabular}{|c|c|c|c|c|c|c|c|c|c|c|c|c|}
\hline $\begin{array}{l}\text { For Italy - Democratic } \\
\text { Centre/Per l'Italia Centro } \\
\text { Democratico (PI-CD) }\end{array}$ & 12 & $1.9 \%$ & 1 & $8.3 \%$ & - & - & - & - & - & - & - & - \\
\hline Brothers of Italy $(\mathrm{FdI})^{\mathrm{c}}$ & 12 & $1.9 \%$ & 3 & $25.0 \%$ & 32 & $5.1 \%$ & 10 & $31.2 \%$ & 32 & $5.1 \%$ & 10 & $31.2 \%$ \\
\hline Totals & 629 & $100 \%$ & 194 & $30.8 \%$ & 630 & 100.0 & 221 & $35.1 \%$ & 629 & 100.0 & 221 & $35.1 \%$ \\
\hline
\end{tabular}

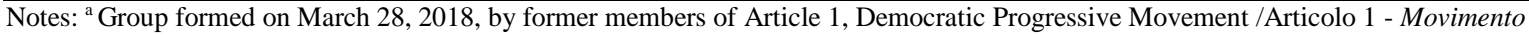
Democratico e Progressista (MDP) and Italian Left-Left, Ecology, Freedom/Sinistra Italiana-Sinistra Ecologia Libertà (SI-SEL). ${ }^{\mathrm{b}}$ Previously called Northern League/Lega Nord (see Political party report).

${ }^{\mathrm{c}}$ Previously called Brothers of Italy-National Alliance/Fratelli d'Italia-Alleanza Nazionale (FdI-AN) (see Political party report).

Source: Camera dei Deputati (2019).

Table 4.2 Party and gender composition of the upper house of parliament (Senato della Repubblica) in Italy in 2018

\begin{tabular}{|c|c|c|c|c|c|c|c|c|c|c|c|c|}
\hline \multirow[b]{4}{*}{ Party } & \multicolumn{4}{|c|}{ 1 January 2018} & \multicolumn{4}{|c|}{23 March 2018, election } & \multicolumn{4}{|c|}{31 December 2018} \\
\hline & \multicolumn{2}{|c|}{ All } & \multicolumn{2}{|c|}{ Women } & \multicolumn{2}{|c|}{ All } & \multicolumn{2}{|c|}{ Women } & \multicolumn{2}{|c|}{ All } & \multicolumn{2}{|c|}{ Women } \\
\hline & $\mathrm{N}$ & $\%$ & $\mathrm{~N}$ & $\%$ & $\mathrm{~N}$ & $\%$ & $\mathrm{~N}$ & $\%$ & $\mathrm{~N}$ & $\%$ & $\mathrm{~N}$ & $\%$ \\
\hline & & & & & & & & & & & & \\
\hline Democratic Party (PD) & 97 & $30.3 \%$ & 41 & $42.3 \%$ & 52 & $16.2 \%$ & 21 & $40.4 \%$ & 52 & $16.2 \%$ & 21 & $40.4 \%$ \\
\hline Five Stars Movement (M5S) & 35 & $10.9 \%$ & 15 & $42.9 \%$ & 109 & $34.1 \%$ & 46 & $42.2 \%$ & 107 & $33.4 \%$ & 46 & $43.0 \%$ \\
\hline Go Italy $(\mathrm{FI})^{\mathrm{a}}$ & 44 & $13.7 \%$ & 5 & $11.4 \%$ & 61 & $19.1 \%$ & 20 & $32.8 \%$ & 61 & $19.1 \%$ & 20 & $32.8 \%$ \\
\hline $\begin{array}{l}\text { Article } 1 \text { - Democratic } \\
\text { Progressive Movement / } \\
\text { Article } 1 \text { - Movimento } \\
\text { Democratico e Progressista } \\
\text { (MDP) }\end{array}$ & 16 & $5.0 \%$ & 5 & $31.2 \%$ & - & - & - & - & - & - & - & - \\
\hline Free and Equals $(\mathrm{LeU})^{\mathrm{b}}$ & - & - & - & - & 4 & $1.2 \%$ & 1 & $25.0 \%$ & 4 & $1.2 \%$ & 1 & $25.0 \%$ \\
\hline $\begin{array}{l}\text { Popular } \\
\text { Alternative/Alternativa } \\
\text { Popolare (AP) }\end{array}$ & 24 & $7.5 \%$ & 4 & $16.7 \%$ & - & - & - & - & - & - & - & - \\
\hline $\begin{array}{l}\text { For Autonomies/Per le } \\
\text { Autonomie (SVP-UV- } \\
\text { PATT-UPT-PSI-MAIE) }^{\mathrm{c}}\end{array}$ & 18 & $5.6 \%$ & 2 & $11.1 \%$ & 8 & $2.5 \%$ & 2 & $25.0 \%$ & 8 & $2.5 \%$ & 2 & $25.0 \%$ \\
\hline League $(\mathrm{L})^{\mathrm{d}}$ & 11 & $3.4 \%$ & 2 & $18.2 \%$ & 58 & $18.1 \%$ & 19 & $32.7 \%$ & 58 & $18.1 \%$ & 19 & $32.7 \%$ \\
\hline $\begin{array}{l}\text { Great Autonomies and } \\
\text { Freedom/Per le Autonomie e } \\
\text { Libertà (GAL) }\end{array}$ & 14 & $4.3 \%$ & 2 & $14.3 \%$ & - & - & - & - & - & - & - & - \\
\hline $\begin{array}{l}\text { Liberal Popular } \\
\text { Alliance/Alleanza } \\
\text { Liberalpopolare (ALA) }\end{array}$ & 13 & $4.1 \%$ & 2 & $15.4 \%$ & - & - & - & - & - & - & - & - \\
\hline $\begin{array}{l}\text { Us With Italy/Noi con } \\
\text { l'Italia (NI) }\end{array}$ & 11 & $3.4 \%$ & 3 & $27.3 \%$ & - & - & - & - & - & - & - & - \\
\hline $\begin{array}{l}\text { Freedom Federation/Federa- } \\
\text { zione della Libertà (FL) }\end{array}$ & 10 & $3.1 \%$ & 2 & $20.0 \%$ & - & - & - & - & - & - & - & - \\
\hline Brothers of Italy (FdI) & 1 & $0.3 \%$ & 0 & $0.0 \%$ & 18 & $5.6 \%$ & 3 & $16.7 \%$ & 18 & $5.6 \%$ & 2 & $11.1 \%$ \\
\hline Others & 27 & $5.9 \%$ & 8 & $42.1 \%$ & 10 & $3.1 \%$ & 2 & $20.0 \%$ & 10 & $3.1 \%$ & 2 & $20.0 \%$ \\
\hline Totals & 320 & $100 \%$ & 93 & $29.1 \%$ & 320 & $100 \%$ & 114 & $35.6 \%$ & 320 & $100 \%$ & 113 & $29.7 \%$ \\
\hline
\end{tabular}

Notes: ${ }^{a}$ Previously called Go Italy-People of Freedom/Forza Italia-Popolo della Libertà

${ }^{\mathrm{b}}$ Group formed by former members of Article 1 - Democratic Progressive Movement / Article 1 - Movimento Democratico e Progressista (MDP) and members of the mixed group belonging to the component Italian Left-Left, Ecology, Freedom/Sinistra Italiana-Sinistra Ecologia Libertà (SISEL).

${ }^{\mathrm{c}}$ From March 23, the abbreviation of the group changed to SVP-PATT, UV reflecting the new composition of the group.

${ }^{\mathrm{d}}$ Previously called Northern League-Autonomies/Lega Nord-Autonomie (see Political party report).

${ }^{\mathrm{d}}$ Group formed by former members of Civic Choice-Liberal Popular Alliance - Authonomies/Alleanza Liberalpopolare - Autonomie (SCALA).

Source: Senato della Repubblica (2019). 


\section{Political party report}

The 2018 elections marked a major shift for the Lega Nord as it culminates its transition from regionalist populism to a distinctively national ideological profile (Albertazzi et al., 2018). The process, which had been ongoing for several years, implied a progressive distancing from the party's traditional attention to the regional autonomy of northern Italy in favour of identity issues and law and order at the national level. The choice was confirmed by Matteo Salvini's decision to amend the name of the party by dropping the term "North", and to personalize the campaign by adding his own name to the electoral symbol: Lega Salvini Premier.

On the left of the political spectrum, the unprecedented vote loss marked by the general elections led PD’s Secretary Matteo Renzi to resign from his position. Former Minister of Agriculture Maurizio Martina took his place ad interim from March to November 2018, when he resigned in view of a national congress to be held in March 2019 where a new leader would be elected.

Table 5. Changes in political parties in Italy in 2018

A. $\quad$ Party institutional changes in 2018

Northern League/Lega Nord (LN) changes its official denomination to run for the elections under the symbol "Lega Salvini Premier"

B. $\quad$ Party leadership changes in 2018

Democratic Party secretary Matteo Renzi (1975, Male, PD) resigned after the poor score at general elections on 05 March; replaced by Maurizio Martina (1978, male, PD) 


\section{Issues in national politics}

Alongside the election and the negotiation on government formation, three major themes dominated politics throughout 2018: the debates about migration to Italy, the discussions on the 2019 budget package, and issues concerning infrastructure and transport.

Migration topped the political agenda throughout the whole year. Prior to the election, LN, FdI and smaller nativist collective actors focused extensively on the idea of migrants as a security and economic threat, while most of the campaigning parties, including the centre-left, have continued to focus on the presence of immigrants as a catalyst for societal tensions. Political conflict escalated in February, when a 28-year-old extreme-right activist named Luca Traini, formerly involved with Lega Nord, went on a shooting rampage in Macerata, a small town in central Italy, wounding five men and one woman of African origin. The following months featured heated public debates on the issue, due to highly mediatised crime stories involving migrants, but also to a series of small and medium-scale episodes of anti-immigrant violence. As Matteo Salvini took up the Ministry of Interior post, the issue of migration reached the core of government action in local, national and supranational politics. At the local level, Salvini praised investigations, and later the arrest for allegedly aiding illegal immigration, of Mimmo Lucano, a mayor that became a model for the integration of hundreds of migrants into the sparsely populated town of Riace in Calabria. At the national level, the lower house approved in November the government-sponsored "security" decree clamping down on asylum rights and hardening security measures as a way of preventing terrorist attacks on Italian soil, which sparked further criticism in parliament and beyond. At the supranational level, the Italian government triggered several standoffs with other European Union member states for it denied 
safe harbour to people rescued by humanitarian ships off the coast of Libya. In particular, Italy entered in a state of latent hostility with France over migration, summoning the French ambassador in response to criticisms by president Macron, sending police to the French border and escalating arguments with local authorities over the return of migrants to Italy. A second important issue in national politics concerned the budget plan for 2019, which triggered disagreement within the government and pressures from top EU officials. The drafting of the spending plan produced lasting tensions between the M5S and Lega components of the government, each one insisting on introducing the economic policies they had campaigned for: basic income and pension reform. Once the two found a compromise, the European Commission rejected the proposed budget for it breached EU fiscal rules and Italian bonds rallied reaching the highest level since 2013. After a three-month battle with European authorities, the Italian government succeeded in preserving the two flagship policies in the plan but was forced to cut several billions from the budget to avert EU sanctions and meet the lower deficit target proposed by the Commission - leaving many commentators predicting an unsuccessful implementation in the medium-term.

Finally, public debates revolved around issues of infrastructure projects. The two government partners showed much disagreement over long-term infrastructural development plans. On the one hand, dramatic events such as the August 2018 Genoa bridge collapse that killed 43 people exacerbated internal tensions and put pressure on the newly appointed M5S minister Danilo Toninelli. On the other, the government had to cope with the highly polarising issue of the High Speed Train/Treno Alta Velocità (TAV) that would link France and Italy under the Alps. While the Lega and its local administrators in the northern regions supported the project, the M5S had 
vociferously opposed it ahead of the elections to consolidate its support among the large portions of Susa valley residents who are hostile to the TAV.

Other relevant issues in 2018 include debates on gun ownership with the League vocally supporting citizens' rights to own guns for self-defence; the controversial "Dignity Decree", sponsored by the M5S to overturn the previous government's acts and introduce elements of labour market reform; and the political reactions following the sudden death of Fiat Chrysler chief Sergio Marchionne. Two court rulings had also profound impacts on public debates. In May, a court ruled that former three-time Premier Silvio Berlusconi was eligible to seek public office again, nearly five years after the tax fraud conviction had banned him from standing for office. In July, a top court in Rome ruled in favour of the seizure of $€ 49$ million from the assets and funds of LN, after an earlier conviction for financial irregularities in 2008-2010, which forced the party leadership to strike a deal to repay the sum over the next 75 years.

\section{Sources}

Albertazzi, A., Giovannini, A. and Seddone, A. (2018). “'No Regionalism Please, We Are Leghisti!' The Transformation of the Italian Lega Nord Under the Leadership of Matteo Salvini'. Regional and Federal Studies, 28:5, pp. 645-671.

Camera dei Deputati (2019). Gruppi Parlamentari. Available at: http://www.camera.it/leg18/46, last accessed 21 January 2019.

Castelli Gattinara, P. and Froio, C. (2018). Italy. European Journal of Political Research Political Data Yearbook, 57(1), 156-161. 
Governo Italiano (2019). Ministri e Sottosegretari del Governo. Available at: http://www.governo.it/ministri-e-sottosegretari, last accessed 21 January 2019.

Ministry of the Interior (2019). Archivio Storico delle Elezioni. Available online at: https://elezionistorico.interno.gov.it/index.php?tpel=C, last accessed 22 January 2019. Senato della Repubblica (2019). Composizione dei Gruppi del Senato nella XVIII Legislatura. Available online at: http://www.senato.it/leg/18/BGT/Schede/Gruppi/Grp.html , last accessed 22 January 2019. 